\title{
Elders as leaders in 1 Peter and the early Church
}

\author{
John H Elliott ${ }^{1}$ \\ University of San Francisco, USA
}

\begin{abstract}
Addressing a hostile situation that called for courageous and exemplary leaders, the letter of 1 Peter employed in 5:1-5 a cluster of vocabulary and images (elders, overseers/exercise oversight, shepherds, flock) representing a growing coalescence of terms for leaders and their functions in the early Jesus movement. As one of the earliest witnesses to this constellation and its symbolization of community leaders as elders-pastors-overseers, the text of 1 Peter 5:1-5a deserves more attention than it has hitherto been accorded in the study of early Christian ministry and church order.
\end{abstract}

\section{INTRODUCTION}

In studies on ministry, leadership and order in the early church, 1 Peter often is given less attention than it deserves. Even when the content of the letter is examined for its bearing on this theme, relevant statements of the text (e.g. 1 Pt 5:1-5a) are sometimes misconstrued or, in other instances, passages irrelevant to the topic of ecclesial leadership, such as 1 Peter 2:4-10 and 1 Peter 4:7-11, are used to develop theories unsupported by the evidence and inconsistent with the content of the letter as a whole. Examples of such exegetical Abwege (errors) will be mentioned in due course. Our main focus of attention in this essay, however, will be the instruction of elders in 1 Peter $5: 1-4$, its unique blend of traditions and motifs, and its significance for a general understanding of the role and responsibilities of elders as leaders in the New Testament period. Most of the exegetical underpinning of what follows is presented in various sections of my recently published commentary on 1 Peter in the Anchor Bible series (Elliott 2000). Given the space limits of

\footnotetext{
${ }^{1} \mathrm{Dr}$ John H Elliott is Professor Emeritus of New Testament, University of San Francisco, California, USA. Permission granted for publication by Dr Ralph W Klein, Christ SeminarySeminex, Professor of Old Testament, Editor of Currents in Theology and Mission. This essay appeared originally in a Festschrift honoring Everett Kalin of Pacific Lutheran Theological Seminary, Berkeley, California (Currents in Theology and Mission 28/6 (2001), 549-559. For as long as our honoree, Ev Kalin, and I have been good friends and colleagues - over forty years from Concordia Seminary, St Louis, onward - 1 Peter has been a constant focus of my research and I offer this morsel of my Lebensarbeit to Ev as a token of my esteem and friendship and in gratitude for Ev as a pastor faithful to the spirit of 1 Peter.
} 
this essay, I shall regularly refer the reader to the commentary for exegetical support of the points presented here in summary form.

\section{PASSAGES OF 1 PETER IRRELEVANT TO THE TOPIC OF LEADERSHIP}

\section{$2.1 \quad 1$ Peter 4:7-11}

At the outset it is important to be clear that 1 Peter 5:1-4(5a) is the only passage of this letter in which the issue of leadership is addressed. Every reader of 1 Peter knows, of course, that significant mention of charismata is made in 1 Peter 4:7-11. This passage, however, has no relevance to the issue of leadership or to charismatic forms of authority, however much this has been assumed in earlier scholarship. 1 Peter 4:7-11, a unit of the letter addressed to the entire community, encourages of all members actions that will strengthen the solidarity of the community in its struggle with a hostile society (Elliott 2000:743-56). This includes "exercising sound judgment and being alert" ( $v 7 b)$, maintaining constant love toward one another" ( $v 8 a)$, "being hospitable to one another" (v 9), "speaking" (v 11a) and "rendering service" (v $11 b)$. All these various activities are interpreted theologically as "charisms," exercises of gifts of grace conferred by God: "Inasmuch as each has received a gift of grace (charisma), serve one another with it as honourable household stewards of God's varied grace" (v 10). The several references here to "each," "anyone," and "one another" and the fact that "each" is said to be a beneficiary of God's grace make it clear that all members of the community are in view, with no distinction between some who are charismatically endowed for leadership and others who are not. The concern is not with leadership by some, but mutual service by all. Thus the charisms of which 1 Peter 4:7-11 speaks have no bearing on the issue of leadership and authority (cf also Elliott 1966:192-196).

Accordingly, the theory that 1 Peter 4:10-11 and 1 Peter 5:1-5 derive from different letters of different authors envisioning contrasting forms of leadership and that leadership by elders was intended to supplant leadership by charismatics (Schröger 1976) is sheer speculation with nothing to commend it.

\subsection{Peter 2:4-10}

A second passage of 1 Peter that often is claimed to bear on the issue of authority and leadership, is 1 Peter 2:4-10. But again the case is otherwise. This ingeniously constructed passage constitutes a powerful conclusion to the first major section of the letter (1:3-2:10), which emphasises the divinely 
conferred dignity of the reborn people of God. Beginning at 1 Peter 1:3, the course of Christian conversion and growth is traced from the believers' rebirth through the mercy of God (1:3-12) to the hope and holiness of God's reborn children, who are redeemed by the holy Christ (1:13-21), the mutual familial love required of those reborn through the word of the Gospel (1:22-25), their nourishment on and continued growth through the word (2:1-3), to their consolidation as the "household of God", which embraces now the elect and holy people of God of the end time. In this depiction of the rebirth, growth, and consolidation of the reborn as the household or family of God, diverse traditions and images are merged to affirm the family's divine regeneration, sanctification, and election, its union with God and Jesus Christ, and its distinction from all nonbelievers (Elliott 2000:406-449). In 1 Peter 2:9-10, several honorary epithets of ancient Israel, all corporate in nature, are used to affirm the believing community as God's elect and holy people: "elect stock" (genos eklekton), "royal residence" (basileion), "priestly community" (hierateuma), "holy people" (ethnos hagion), "people for [God's] possession" (laos eis peripoiêsen), "God's people" (laos Theou). All these epithets are corporate in nature and express not the qualities of individuals but rather the privileged character of the community as God's elect and holy people. Drawn mainly from Israel's exodus and covenant traditions (Ex 19:3-6; Is 43:20-21; but also Hs 1-2), these communal epithets identify the believing community as the eschatological covenant people of God, elected and sanctified by God from among all the peoples. Like the expression "elect stock" derived from Isaiah 43:20-21, the terms basileion (royal residence), hierateuma (priestly community) and ethnos hagion (holy people) deriving from the LXX version of the covenant formula of Exodus 19:6, all emphasize the elect and holy character of community.

This emphasis on election pervades the entire unit of 1 Peter 2:4-10, as its structure as well as its terminology make clear. In verse 4 Jesus the Lord (cf 2:3) is declared, in terms derived from Isaiah 28:16 (quoted in 2:6), to be the "living stone" that was rejected by humans but who is "elect (eklekton), honoured in God's sight." In verse 5 where the focus shifts from Jesus to the community, the election and covenant terms hierateuma and hagios (deriving from Ex 19:6, cited in verse 9) supply the terms of verse $5 e$ ("holy priestly community"). Similarly, the associated election and covenant term basileion (Ex 19:6, cited in verse 9) is interpreted in verse $5 d$ as "house(hold) of the Spirit." In verse 6 the citation of Isaiah 28:16 speaks of a stone set by God in Zion that is "a cornerstone, elect (eklekton), honoured." Finally in verse 9 those who believe in Jesus Christ as the "elect stone" and who are honoured as he was honoured ( $v v 4 d, 7 a)$ are themselves declared to be an "elect 
stock" and God's elect and holy people with terms deriving from Israel's election and covenant tradition ("royal residence," "priestly community," "holy people"). This emphasis on the divine election of the household of God relates this passage to both the opening and close of the letter, where both addressees and the brotherhood at Rome are described as the "elect" or "coelect" of God $(1: 1 ; 5: 13)$. Thus the theme of election weaves through this letter from beginning to end and in 2:4-10 receives its fullest explication.

This passage was read in quite a different light by Martin Luther who was interested less in the meaning of 1 Peter 2:4-10 as a whole than in the term hierateuma $(2: 5,9)$ and the theological use to which this term could be put in the formulation of a new, more biblically based doctrine: das Priestertum aller Gläubigen, the priesthood of all believers. In criticism of the cleavage between the clergy and laity of his day and a monopolization by the former of the means of grace, the great Reformer insisted on the equality before God of all the baptized. Through baptism, he asserted, all believers are consecrated as priests (WA 6.407.22-25; cf also 6.564.6-7), pointing to 1 Peter 2:9 (and Rv 5:10) as the biblical basis for this thought. This priesthood of all believers complements the priesthood of the officially ordained, he maintained, and both general and specific priesthoods participate, each in its own fashion, in the priesthood of Christ. (For relevant texts and for a fuller discussion of this doctrine in relation to 1 Pt 2 see Elliott 1966:2-5; Elliott 2000:449-455).

In general it must be acknowledged that Luther's thoughts on this subject were prompted more by theological than exegetical concerns. Detailed, exegetical investigations of 1 Peter 2:4-10 in modern time (e.g. Cerfaux 1939:5-39; Blinzler 1949:49-56; Elliott 2000:406-449 among others) have shown that this passage has little if anything to do with the notion of a priesthood of all believers as expounded by Luther and those following his lead. (For the numerous treatments of this doctrine see Elliott 2000:455, n 73). The focus of 1 Peter 2:4-10 is not on individuals but on the believing community as a whole, as all the collective terms of verses 5,9 and 10 make clear. The term employed in verses 5 and 9 is not hiereis ("priests") but hierateuma, a collective term ("body, community of priests"), as are most nomina actionis ending in the suffix -euma; e.g. strateuma ("army", "body of soldiers"), techniteuma ("guild of artisans") (Elliott 1966:64-70). Luther's choice of Priestertum as a rendition of hierateuma is, like the English "priesthood", an abstract noun that fails to convey the collective force of the original. Moreover, it is not priesthood, but rather election that is the central and unifying concept of this passage. And whereas nothing is said of priestly community or priesthood elsewhere in 1 Peter, election constitutes a major 
theme from start to close. The term hierateuma derives from the ancient covenantal formula of Exodus 19:3-6, whose focus is the divine election and sanctification of the household of Jacob (Ex 19:3). In this covenantal formula hierateuma expresses the sanctity of the covenant people and its immediate proximity to God, not the individual status of individual priests or kings. No mention is made in 1 Peter 2:4-10 of baptism or any baptismal consecration to priesthood. Nor is any mention made here of believers participating in the priesthood of Jesus Christ, another element of Luther's doctrine drawn from an entirely different writing, namely the Epistle to the Hebrews.

In sum, the claim that 1 Peter 2:5 and 9 constitute the locus classicus for the notion of a "priesthood of all believers" is exegetically unwarranted. That the doctrine of a priesthood of all believers may have other biblical moorings is a possibility worthy of consideration. That it reflects the sense of 1 Peter 2:4-10, on the other hand, is out of the question. Since 1 Peter 2:4-10 is focused exclusively on the community and not its individual members or leaders, it must be concluded that the passage contains no information relevant to the issue of leadership. 1 Peter 5:1-5a, on the other hand, is the one and only passage that deals directly with this issue and so it is this pericope to which we now turn.

\subsection{Peter 5:1-5a and context}

1 Peter 5:1-5a, containing an address to elders (presbyteroi, 5:1-4) and younger persons (neôteroi, 5:5a) forms part of the concluding section of the letter (4:12-5:11), which speaks of honour and joy in suffering (4:12-19), responsible elders and subordinate younger persons (5:1-5a) and the mutual humility of all, resisting the Devil, and trusting in God (5:5b-11) (Elliott 2000:809-844). In 1 Peter 5:1-4, the author addresses the elders (presbyteroi, $5: 1$ ) in his capacity as a "co-elder" (sympresbyteros, $5: 1 \mathrm{a}$ ), "and witness to the sufferings of the Christ" (5:1b), "and sharer in the glory about to be revealed" (5:1c). These characterizations relate to important themes developed throughout the letter; for the second designation see $1: 11 ; 2: 21 b ; 23 ; 3: 18 a$; 4:13; for the third, $1: 5,7-8,11,13 ; 4: 13,14$. The use and perhaps coinage of "co-elder" (attested nowhere else in Greek literature), in particular, rather than "apostle" (cf 1:1), underlines the collegiality that the author wishes to establish between the elders he addresses and himself as fellow elder. As the details of verses 1 Peter 2-5a make clear, these elders were not simply persons older in age, but seniors in households (and in all likelihood seniors in their longevity as believers) who, because of their prestige and status in the household churches of which they were the household heads (Campbell 1994), were recognized and respected as leaders of their respective household churches. 
As leaders, these elders are exhorted to "shepherd the flock of God among you", ( $\mathrm{v} 2 \mathrm{a}$ ) by "exercising oversight" ( $\mathrm{v} 2 \mathrm{~b}$ ) in a responsible manner spelled out by a triad of qualities unique in the New Testament (vv 2c-3). As a consequence of their responsible leadership, they are promised that when the "chief Shepherd" (Jesus Christ, of 2:25) is manifested, these "undershepherds" will receive "the unfading crown of glory" (v 4). To these honourable elders-leaders, the younger persons (i.e. the recent converts of the community, the novices in faith) are to be subordinate (v $5 a$ ).

Throughout the ancient world, both in Greco-Roman and Israelite circles, heads of households respected for their age and prestige were known as "elders" (zekanim, presbyteroi, gerontes, seniores) and exercised the role of local leadership (Campbell 1994). By the time of 1 Peter (ca 73-92 CE), this traditional form of leadership also was firmly in place among the households of the messianic movement. Although Paul makes no explicit mention of elders in his letters, their presence in areas visited by Paul is likely, given the leading role of household heads like Stephan, a senior in the faith (an "early convert in Achaia," 1 Cor 16:15), whom Paul calls a "fellow worker and labourer" (1 Cor 16:16) but who was an elder in all but name. This likelihood is strengthened by the fact that the author of Acts notes that the earliest Jerusalem church was led by "apostles and elders" (Ac 15:2, 4, 6, 22, 23; $16: 4$; cf $11: 30 ; 21: 18$ ) and that Paul and Barnabas appointed such elders in each congregation on their first missionary journey (Ac 14:23). Elders also functioned as leaders in Asia Minor, the area to which 1 Peter was addressed (1 Pt 1:1), as attested by a variety of writings including Acts (20:17), 1 Timothy (5:17-22), 2 John ( $v 1$ ), 3 John ( $v 1$ ) and the later letters of Ignatius (Magn 2:1; 3:1; 6:1; 7:1, 2; 12:2; Phld inscr; 7:2; 10:2; Pol. 6:1) and Polycarp (Phil inscr; $5: 3 ; 6: 1$ ). They likewise functioned as leaders at Corinth ( 1 Clem 1:3; 3:3; $21: 6 ; 44: 5 ; 47: 6 ; 54: 2 ; 57: 1$ ) and Rome (1 Clem 21:6; 44:5; Herm Vis 2.4.2, 3; 3.1.8).

A noteworthy feature of our Petrine passage is the pastoral imagery and verb episkopountes used to describe the task of these elders. The Christian community is referred to as "the flock of God" and the elders are urged to "shepherd" (poimanete) this flock (to poimnion) "by exercising oversight "(episkopountes) (5:2). To "exercise oversight" or to be an episkopos, involves "the responsibility of safeguarding or seeing to it that something is done in the correct way", to function as a "guardian" (BDAG, under episkopos, 379). Thus the verb episkopountes fits well both with elders and especially the function of shepherding. The depiction of God's people as a "flock" or as "sheep" under the guidance and care of God or human leaders as "shepherds" (poimanes, poimainein) has familiar Old Testament roots. (On 
the pastoral metaphor in general and its use in 1 Peter, see especially Bosetti 1990). Jesus applied the pastoral metaphor to himself and his disciples (Mk 6:34/Mt 9:36; Mk 14:27/Mt 26:31; Jn 10:1-18) and, according to John 21:1517, commissioned Peter in particular to "feed my lambs ... shepherd my sheep ... feed my sheep". In 1 Peter, the pastoral metaphor is used of Jesus Christ in 2:25 and 5:4.

As a term for Christian leaders, "shepherd" as either a verb or a noun, is employed in other texts as well (Ac 20:28; Eph 4:11; Ign, Phld 2:1; Rm 9:1; Ascen Isa 3:23-27; Herm, Vis. 5.5; Sim. 9:31.5-6). Acts 20:17-35, recounting Paul's farewell address at Miletus to the elders of Ephesus, is particularly noteworthy because of the cluster of terms it shares with 1 Peter $5: 2$. Here the Ephesian "elders" (presbyteroi, Ac 20:17) are urged to "take heed to yourselves and to all the flock (tō poimniō) over which the Holy Spirit has made you overseers (episkopous) to shepherd (poimainein) the church of the Lord" (Ac 20:28). While the similarities suggest the influence of common tradition, 1 Peter and Acts, both composed in the final third of the first century, provide the earliest evidence of a developing trend to attribute to elders the function of oversight and to portray elders and overseers as shepherds of the flock. Three terms are brought together here - elders (presbyteroi), overseers (episkopoi, episkopein), shepherds (poimanes, poimainein) - in a manner that indicates their initial synonymous use as designations for Christian leaders. The somewhat latter writings of 1 Timothy (3:1, episkopos; 5:17-22, presbyteroi) and Titus (1:5, presbyteroi; 1:7, episkopos) still attest a similar synonymity of "elder" and "overseer" and the singular episkopos still appears to be one of the several elders. The diakonoi of which the Pastorals also speak (1 Tm 3:8-10, 12-13; cf $2 \mathrm{Tm} 4: 10$ ) appear to constitute a further emerging group of functionaries known as "deacons" (cf Ac 6:1-6 and Phlp 1:1; 1 Clem 42:4-5; Polyc, Phil 5:2; Ign, Eph 2:1 and passim; Herm, Vis 3.5.1; Sim 9.26.2). Clement of Rome (ca 96 CE) likewise describes elders functioning as episkopoi ( 1 Clem 44:1-6) and in 44:3-5 "flock of Christ", "oversight", and "elders" occur in tandem similar to 1 Peter 5 and Acts 20. The fact that 1 Clement, Didache and the Shepherd of Hermas speak only of overseers in the plural (with the exception of $1 \mathrm{Clem} 59: 3$ where God is identified as ktistên kai episkopon) is consistent with their equation of presbyteroi and episkopoi. It also indicates that among the churches producing these writings (communities at Rome in the case of $1 \mathrm{Clem}$ and Hermas [mid-second century]) nothing is known of a monepiscopate. 


\title{
3. A NEW AND DIFFERENT PATTERN WITH IGNATIUS OF ANTIOCH
}

The letters of Ignatius of Antioch (C $106 \mathrm{CE}$ ), on the other hand, marked a new and different concept of order presumed among the churches addressed. Ignatius distinguished between a plurality of elders and a singular episkopos (Ign, Eph 1:3; 4:1; Magn 2:1; Trall 1:1 Phld 1:1; Smyrn 8:1 and passim). It is the bishop (episkopos, Rm 2:2) of Antioch in Syria who first makes a distinction between the roles, titles, and statuses of presbyteroi, episkopoi, and diakonoi and who describes the pattern adopted more universally in later time. Ignatius advocated a pattern aimed at strengthening the unity (Eph 5:1; Phld inscr, 3:2-3) and orthodoxy (Eph 6:2; 16:1-2; Magn 11:1; Trall 6:1-2; Smyrn 6:1-2 etc) of the churches and warranted by divine authority (e.g. Eph 3:2; Trall 3:1; Smyrn 9:1). In this pattern, certain persons from among the presbyteroi and the college of presbyteroi (presbyterion, Eph 2:2; 4:1) were chosen as primi inter pares, first among equals, to preside over all other presbyteroi and diakonoi (Magn 2:1; 4:1) and for them the title episkopos was reserved. To this local episkopos and the college of elders all believers were to be subordinate (Magn 13:1-2; Trall 2:1-2; 7:2; 13:2; Phld 7:1-2; Smyrn 8:12). This shift in the status and role of the episkopos to presiding and superordinate elder is usually indicated by a concommitant shift in terminology whereby episkopos can be rendered "bishop" rather than "overseer". The term diakonoi, in turn, designated subordinate ministers assisting the bishops and presbyters as "deacons" (Magn 6:1; Trall 7:2; Phld 4:1; 7:1; Polyc 6:1). This reflects for the first time a hierarchical structure demarcating three distinct levels of authority and competence:

\author{
episkopos/bishop \\ presbyteroi/elders \\ subordinate to episkopos/bishop \\ diakonoi/deacons \\ subordinate to bishop and elders
}

In this arrangement, the role of shepherd/pastor (poimên) appears reserved for the episkopos/bishop alone (Ign, Phld 2:1; cf Rm 9:1-2), an additional harbinger of later development following the Ignatian pattern, and topos ("position") takes on the sense of "office" (Polyc 1:2; cf Smyrn 6:2). 
This stratified Ignatian arrangement is a more elaborated and rationalized form of church order than anything found in the New Testament, though the Pastorals come closest. In fact it differs also from 1 Clement, the Didache, and the Shepherd of Hermas, all of which speak of episkopoi only in the plural (1 Clem 42:4, 5; Did 15:1; Herm, Sim 9.27.2) and equate episkopoiloverseers and presbyteroi/elders. It is also noteworthy that while Ignatius refers to Polycarp of Smyrna as episkopos/bishop (Polyc inscr), Polycarp himself in his letter to Philippi makes no use of the term episkopos, but identifies himself only as "Polycarp and the elders with him" (Phil, inscr). Such diversity in the nomenclature for ecclesial leaders and the equation or demarcation of their functions and statuses reveals a concomitant diversity in the structure and order of the early churches that prevailed down through the mid-second century. While 1 Peter and other New Testament writings contain the building blocks for a hierarchical pattern as advocated by Ignatius, it is only with Ignatius that these building blocks are integrated into a pattern that can be described as stratified or hierarchical in nature. Accordingly, only with the point of development reflected by lgnatius is it appropriate to speak of an attempt at the "institutionalization" and rationalization of distinctive modes and levels of leadership involving distinct levels of authority, distinct roles, and differentiated "offices". One important implication for this state of affairs is that the term "office", which presumes the institutionalization of a bureaucratic form of governance, is a historically anachronistic and sociologically inaccurate designation for the roles and functions described in the New Testament and ought to be avoided in all discussions of New Testament leadership and church order.

\section{1 PETER 5 IN VIEW ONCE MORE}

1 Peter, in particular, reflects no such stage of institutionalization and addresses persons who are not "office-holders" but rather heads of household churches known traditionally as "elders," who as "shepherds" are urged to "oversee" (not "act as bishops of") the flock of God in a manner befitting "under-shepherds," as it were, of Jesus Christ, the Chief Shepherd. The "serving" of which it speaks (diakonein, 4:11) is not reserved to functionaries known as "deacons," but is an activity made possible by the divine grace conferred on all believers (4:10).

The mode and motivation for responsible leadership is spelled out in a triad of negative-positive antitheses (1 Pt 5:2c-3) that is unique in the New Testament while also reflecting a blending of tradition: 
Elders as leaders in 1 Peter and the early Church

Not because compelled [to do so] not for shameful gain

not as domineering those allotted [to you] but willingly in accord with God

but eagerly

but being examples for the flock

The point made here is that pastoral leadership must be freely and willingly undertaken "as God would have you do it" (NRSV), with no trace of selfserving or "lording it over" the flock.

Elders/shepherds exercising oversight are to act in accord with God's will, ever mindful of the fact that the flock is not theirs to dominate but God's (cf v 2a) and that it is God who has "allotted" these sheep to their charge ( $v 3$ ). Their task is to lead by example and not as overlords. A domineering mode of leadership can be avoided only when elders "walk the talk" and lead not by domination but by inspiration. The final member of this triad ( $v 3$ ), with its term katakyrieuontes ("domineering") and its call for serving by example has linguistic and conceptual affinities with Jesus' instruction of his disciples concerning the nature of appropriate discipleship (Mk 10:35-45/Mt 20:2028/Lk 22:25-27). Since Mark 10:42/Mt 20:25 are the only other New Testament occurrences of the verb katakyrieuô (cf kyrieuô, Lk 22:25), it appears that the Petrine author has incorporated a reminiscence of this dominical logion into his triad of antitheses. The disciples, Jesus insisted, are not to be concerned with precedence, power, and who among them is greatest. In contrast to Gentile rulers who "domineer" or "lord it over" (katakyrieuousin) their subjects, Jesus' disciples to take Jesus their leader as their example and to serve as did the Human One who "came not to be served but to serve and to give his life as a ransom for many" (Mk 10:45/Mt 20:28; also John 13:1-15 for a similar emphasis on Jesus as humble servant and example). According to the Petrine author, as Jesus was God's humble servant and example for believers (see the same thought in $1 \mathrm{Pt}$ 2:21-23), so leaders, like all believers, are to "follow in his steps" ( $\mathrm{v} 2: 21 \mathrm{~d})$ and as leaders provide a similar model for all believers to follow ( $\vee 5: 3$ ). The emphasis on humility implied in Jesus' instruction and example is echoed here and is expressed explicitly in 5:5b-7 where the entire community is addressed and the mutual humility of all believers is enjoined. When elders conduct themselves as instructed in verses 2-3, these faithful "under-shepherds" can be confident that when the chief Shepherd is manifested at the close of the age, they shall receive "the unfading crown of glory" $(v 4)$.

A final reference to these elders occurs in 1 Peter 5:5a. In this accompanying address to "younger persons" (neôterol), best taken as a reference to recent converts, these persons who are young in the faith are 
instructed to maintain order and unity within the community by subordinating themselves to the elders and giving them the respect they deserve (Elliott 2000:836-841).

When 1 Peter $5: 1-5 a$ is seen in connection with $5: 5 b-11$, which addresses the entire community, a relativization and limitation of the authority of these elders/leaders becomes even clearer. Here elders/leaders are included among all believers who are enjoined to "clothe yourselves with humility in your relations with one another because 'God opposes the arrogant but gives grace to the humble"' (5:5c, citing $\operatorname{Pr} 3: 34$ LXX). Elders, like household slaves $(2: 18-25)$, wives $(3: 4)$, and all the believers $(3: 8 ; 5: 5 b-7)$, are to exemplify in their lives and conduct the humility manifested by the Christ (2:21-23), for humility is a fundamental characteristic of those favoured by God.

\section{CONCLUSION}

The cluster of vocabulary and images (elders, overseers/exercise oversight, shepherds, flock) contained in 1 Peter 5 represents a growing coalescence of terms for Christian leaders and their functions that will continue far beyond the time of this letter. As one of the earliest witnesses to this constellation and its symbolization of Christian leaders as "pastors", the text of 1 Peter 5:1-5a deserves more attention than it has hitherto been accorded.

The traits of leadership which the Petrine author outlines had a direct relation to the precarious situation in which the addressees of the letter found themselves. For communities of believers under pressure from Gentile outsiders to compromise their exclusive allegiance to God and Jesus Christ, to soft-pedal the holiness that set them apart from others, to "go along in order to get along" in order to avoid insult, reproach, public shaming and the suffering such mistreatment entailed $(1: 6,14-17 ; 2: 11-12,15-16,18-20 ; 3: 9$, $13-17 ; 4: 1-4,12-19 ; 5: 8-9)$, courageous and competent elders were needed to lead the way and help "take the heat" of society's scorn. The maintenance of the social cohesion and religious commitment of God's flock required pastors who willingly accepted the role of leadership, who were committed to carrying out the will of God, who sought not their own personal gain but rather the welfare of the flock, and who exercised their oversight not as overlords but as under shepherds of the Chief Shepherd. In emulating the humility of the Christ, they, in turn, would be examples of the humility that was to characterize and bond the entire community. 


\subsection{Peter 5 and the church today}

The church of the present finds itself in a situation far different from that faced by the beleaguered addressees of 1 Peter. No longer a minority messianic sect threatened by social absorption and extinction, the church today has a firm place and a respected voice in the corridors of power. Accordingly, one might claim that only in those exceptional instances where pockets of the church encounter hostile opposition and persecution could these Petrine words to elders be found "relevant" and "empowering". On the other hand, could one not also propose that 1 Peter 5 also speaks to issues of ecclesial leadership typical of each and any generation, differences in political and social conditions notwithstanding? This would include instances where leadership roles are foisted upon the timid rather than accepted willingly by the courageous; where there are self-appointed pastors-for-profit and merchandisers of God's grace; where pastors treat the flock not as God's but as their own; where overseers and bishops attempt to command from top down like princes of the church rather than as shepherds who lead by humble example? With regard to such instances of corrupt leadership, would it be that much of a hermeneutical leap to suggest that these words of 1 Peter continue to indicate the qualities, spirit, and motivation that should mark the leaders of the church in any age?

\subsection{A cautionary afterthought}

After the completion of this article, I happened to glance through some recent issues of The Lutheran, a parish magazine of the Evangelical Lutheran Church in America. Virtually every issue carried some report about the ELCA's recent full communion agreement with the Episcopal Church, Called to common mission. These reports often mentioned objections to that agreement by a minority within the ELCA who discount the historic episcopate as an authentic element of the ministry and structure of the Church Catholic and hence of both Lutheran and Episcopal communions. Suddenly it occurred to me that a final comment in this present essay was necessary to forestall any misunderstanding and misuse of this essay by persons opposed to the historic episcopate on the grounds that it is not present in 1 Peter or the rest of the New Testament, and since non-biblical, therefore not an authoritative element of the church's heritage.

Therefore I wish to make perfectly clear that nothing stated in this article supports such opposition. What we see in 1 Peter is one early phase of a long development. What Paul, 1 Peter, Acts, the Pastorals, 1 Clement, Hermas, the Didache, and Ignatius of Antioch say about leadership/ministry and order in the early Church represents different steps on a journey taken at 
different times and in different places under differing sets of historical and social circumstances. These diverse writings give witness to a historical, social, and theological process in which over the course of several centuries a form of ministry and order took shape which eventually settled on a threefold form of leadership (bishop, elders and deacons) and an Episcopal form of church governance. The regularization of the transmission of personal authority from bishop to bishop constituted one of three interrelated means for measuring and maintaining the truth of proclamation and practice throughout the church. Preaching, teaching, confession, worship and behaviour had to be in conformity with the authoritative written Scriptural canon, the living canon of the confessing and worshiping community, and the personal authoritative witness to the Gospel commencing with the apostles and transmitted thereafter to their personal successors in diverse localities. In the regard to the personal witness by the episkopoi succeeding the apostles, Irenaeus of Lyons (ca $180 \mathrm{CE}$ ) underlined both the historical actuality of this succession, as 1 Clement had earlier $(42: 2-4 ; 44: 2-3)$, and its function of maintaining the truth of the faith: "It is within the power of all, therefore, in every church, who may wish to see the truth, to contemplate clearly the tradition of the apostles manifested throughout the whole world; and we are in a position to reckon up those who were by the apostles instituted bishops in the churches, and [to demonstrate] the succession of these men to our own times" (Against the Heresies 3.3.1). This threefold constellation of canonical authority assured a system of checks and balances preventing, or at least limiting, the dominance of only one norm of the faith over the others, thereby forestalling a fall into sheer Biblicism, or heterodox confession and worship, or Episcopal domination and monopolization of authority. Each was essential to keeping the faith faithful to its origins while also responsive to ever new exigencies of the present.

In particular, the threefold ministry, including the episcopate, was adopted and institutionalized as the most effective means for coordinating and ordering the ministries of the church in its proclamation of the gospel, its sacramental activity, and its evangelical witness and service to society. (For studies of these developments see, inter alia, the several relevant essays in Eucharist and Ministry 1970; Goppelt 1970; Delorme 1974; and Lienhard 1984; Noll 1993.) The fact that neither 1 Peter nor any other New Testament writing reflects such an ecclesial structure cannot be used to reject this structure as "unbiblical" or "anti-biblical" or inconsistent with Lutheran history and theology. This is the case for at least three reasons.

Firstly, this structure is the end result of a process, a historical and ecclesial development, of which the churches of the New Testament did have 
a part. As noted above, elements or building blocks employed in this structure were already in place in various ways among the New Testament communities. What the threefold ministry represents is a structure in which these building blocks of roles, functions, and terms have been employed, modified, and consolidated. As early as Ignatius it was also believed that this structure assured the unity and orthodoxy of the church and that it had divine warrant. To ignore or dismiss this fact of historical process would be to discount the church as a historical entity which grew and developed variously over time.

Secondly, to insist that only that structuration of Christian ministry that is found in the New Testament is valid, would amount to the rankest form of Biblicism. For Lutherans to so argue would be to espouse a position at complete variance to their own theology, their embrace of the ecumenical creeds of the $4^{\text {th }}$ and later centuries, their liturgy which is an amalgam of several post-biblical rites, and their own Lutheran symbols of the faith.

Finally, the threefold ministry is part of the historical and ecclesial development in which the present Lutheran Church and the ELCA currently stand. To deny this would be to deny the catholic roots and heritage of the Lutheran church - a move that would have been abhorrent to Luther and his fellow reformers and a position never taken by them.

The minority within the ELCA who today persist in questioning or rejecting the threefold ministry and the historical roots of the episcopate as realities that have shaped the Lutheran church from Luther onward run the grave risk of succumbing to an anti-historical and Biblicist mentality at complete odds with the historical consciousness and catholic theology of the Lutheran church from the $16^{\text {th }}$ century to the present.

\section{Works consulted}

Blinzler, J 1049. Episcopus: Studien über das Bischofsamt. Michael von Faulhaber Festschrift, edited by the Theologische Fakultät der Universität München, 4965. Regensburg: Gregorius.

Bosetti, E 1990. II Pastore: Cristo e la chiesa nella Prima lettera di Pietro. Associazione Biblical Italiana. Supplementi alla Rivistas Biblica 21. Bologna: Dehoniane.

Campbell, R A 1994. The elders: Seniority with earliest Christianity. Edinburgh: T\&T Clark.

Cerfaux, L 1954. Regale Sacerdotium. Revue de sciences philosophiques et théologiques 28 (1939), 5-39; reprinted pp 283-315 in vol 2 of Recueil Lucien Cerfaux: Études d'exégèse et d'histoire religieuse. Gembloux: Duculot. (BETL 6-7.)

Danker, F W (ed) 2000. A Greek-English Lexicon of the New Testament and other Early Christian Literature, 3rd ed. Chicago, IL: University of Chicago Press. 
Delorme, J (ed) 1974. Le Ministère et les Ministères selon le Nouveau Testament. Parole de Dieu 10. Paris: Seuil. (BDAG.)

Elliott, J H 1966. The elect and the holy: An exegetical examination of 1 Peter 2:4-10 and the phrase Basileion Hierateuma. Graduate Study VII of the Concordia Seminary School for Graduate Studies. Leiden: Brill. (Suppl to Novum Testamentum Vol XII.) Reprinted by Wipf \& Stock, Eugene, Oregon, 2005.

Elliott, J H 2000. 1 Peter: A new translation with introduction and commentary. New York: Doubleday (Random House). (The Anchor Bible 37B.)

Empie, P C \& Murphy, T A (eds) 1970. Eucharist and ministry. Lutherans and Catholics in dialogue, IV. New York: U S A National Committee of the Lutheran World Federation.

Goppelt, L 1970. Church government and the office of the bishop in the first three centuries, in Asheim, I \& Gold, V R (eds), Episcopacy in the Lutheran Church?: Studies in the development and definition of the office of church leadership, 1-29. Philadelphia, PA: Fortress.

Lienhard, J T 1984. Ministry. Wilmington, DE: Michael Glazier. (Message of the Fathers of the Church, 8.)

Noll, R R 1993. Christian ministerial priesthood: $A$ search for its beginnings in the primary documents of the apostolic fathers. San Francisco, CA: Catholic Scholars Press.

Schröger, F 1976. Die Verfassung der Gemeinde des ersten Petrusbriefes, in Hainz, $\mathrm{J}$ (Hrsg), Kirche im Werden, Studien zum Thema Amt und Gemeinde im Neuen Testament. Munich: F Schöningh. 